\title{
Biological DATA ON TWO HECTOR'S BEAKED WHALES, MESOPLODON HECTORI, Stranded in Buenos Aires province, Argentina
}

\author{
Humberto Luis Cappozzo ${ }^{1,5,}$, María Fernanda Negri ${ }^{1}$, Bettina Mahler ${ }^{1,2}$, \\ Verónica V. Lía ${ }^{2}$, Pablo MartíneZ ${ }^{3,4}$, Adriana Gianggiobe ${ }^{3}$ and Alejandro Saubidet 3,5
}

\begin{abstract}
Beaked whales or ziphiids are the least known cetaceans, and are among the least studied of all mammalian groups. In August and September of 2002, a male and a female beaked whale stranded alive on the Argentine coast, $110 \mathrm{~km}$ away from each other. The specimens died shortly after the stranding and their bodies were collected for dissection and analysis. The specimens were identified as belonging to the genus Mesoplodon. Further measurements of the skulls, shape and location of teeth as well as molecular analyses of the mtDNA control region and cytochrome $b$, allowed unambiguous identification of both specimens as Hector's beaked whale, Mesoplodon hectori. The color pattern was different between male and female. Standard length was 3.94 meters for the male and 3.84 meters for the female. The female's vertebral formula was C7 + T10 + L11 + Ca21 $=49$. Histo-pathological analysis of the female revealed the presence of Sarcocystis sp. in the skeletal muscle, and lung lesions related to parasitic damage and pneumonia or chronic infection. The stomach of both individuals was empty. The digestive tract of both specimens was infected by larval stages L4 of Anisakis sp. The female was also infected by Tetrabothrius sp. and Bolbosoma sp. while Braunina cordiformis was only found in the male. Different composition of parasitic fauna suggests possible sex-related differences in the diet or individual variability. Total length, teeth eruption (in the male) and the degree of vertebral epiphyses fusion suggest that both individuals were mature.
\end{abstract}

Resumen: Las ballenas picudas o zífidos son los cetáceos menos conocidos y además están entre los mamíferos existentes que menos se conocen. En agosto y septiembre de 2002 un macho y una hembra de ballenas picudas vararon vivas en la costa de Argentina, a 110 kilómetros una de otra. Los especimenes murieron poco después del varamiento y sus cuerpos fueron colectados para su disección y análisis. Los especimenes fueron identificados como pertenecientes al género Mesoplodon, a partir de medidas del cráneo, la forma y posición de los dientes y el análisis del ADNmt, región control y citocromo $b$, permitiendo identificar sin ambigüedad ambos especimenes como ballenas picudas de Héctor, Mesoplodon hectori. El macho y la hembra presentaron diferente patrón de coloración. La longitud estándar fue de 3,94 metros para el macho y de 3,84 metros para la hembra. La fórmula vertebral de la hembra fue C7 + T10 + L11 + Ca21 = 49. Análisis histopatológicos de la hembra revelaron la presencia de Sarcocystis sp. en el músculo esquelético, y lesiones pulmonares relacionadas con daño producido por parásitos y pneumonía o infección crónica. El estómago de ambos ejemplares se encontró vacío. El tracto digestivo de ambos especimenes se encontraba infectado por el estadio larval L4 de Anisakis sp. La hembra tenía Tetrabothrius sp. y Bolbosoma sp. Mientras que el macho tenía Braunina cordiformis en su estómago. La diferente composición de la fauna parasitaria de ambos individuos sugiere la existencia de posibles diferencias en la dieta relacionadas al sexo o variabilidad individual. La longitud estándar, la erupción de los dientes (en el macho) y el grado de fusión de las epífisis vertebrales sugieren que ambos ejemplares eran maduros.

Key words: Mesoplodon hectori, biology, distribution, morphology, stranding, western South Atlantic, Argentina, beaked whales, genetics.

\section{Introduction}

Beaked whales (family Ziphiidae) are poorly known cetaceans and among the least studied of all mammalian groups (Dalebout et al., 1998). Twenty-one species of these pelagic cetaceans have been described to date. One of them (Perrin's beaked whale, Mesoplodon perrini) was described as a new species only recently with the help of molecular techniques as it is morphologically almost indistinguishable from Hector's beaked whale, $M$. hectori (Dalebout et al., 2002). Out of 21 ziphiid species, 14 belong to the genus Mesoplodon, which is the most diverse genus among all cetaceans (Dalebout et al., 1998; 2004; Mead, 2002; Pitman, 2002). Their preferential habitat is deep oceanic waters which makes them difficult to observe or strand. All Mesoplodon species are known only from a few records and are considered rare or very rare (e.g. Pitman, 2002). They have been observed entangled in fishing gear around the world (Henshaw et al., 1997) or taken in small whaling fisheries in the Northern Hemisphere (Walker et al., 2002). In the Southern Hemisphere most of the information about Mesoplodon whales has been obtained from strandings (e.g. Goodall, 1978; Sekiguchi et al., 1996; Baker et al., 2001; Zerbini and Secchi, 2001; van Helden et al., 2002; Martins et al., 2004; Laporta et al., this issue; Souza et al., this issue). Mesoplodon species are very similar, rare and difficult to identify from sightings at sea and even from strandings (e.g. Gales et al., 2002; Pitman, 2002; Laporta et al., this issue).

\footnotetext{
${ }^{1}$ Laboratorio de Ecología, Comportamiento y Mamíferos Marinos, Museo Argentino de Ciencias Naturales "Bernardino Rivadavia" and Estación Hidrobiológica de Puerto Quequén (MACN-CONICET). Av. Angel Gallardo 470, C1405DJR, Buenos Aires, Argentina. 2 Departamento de Ecología, Genética y Evolución, Facultad de Ciencias Exactas y Naturales, Universidad de Buenos Aires, Buenos Aires, Argentina.

${ }^{3}$ Fundación Mar del Plata Aquarium, Mar del Plata, Argentina.

${ }^{4}$ Instituto Nacional de Investigación y Desarrollo Pesquero, Mar del Plata, Argentina.

${ }^{5}$ Centro de Estudios Mar del Plata, Universidad Tecnológica Nacional. Mar del Plata, Argentina.

"Corresponding author: Museo Argentino de Ciencias Naturales "Bernardino Rivadavia". Av. Angel Gallardo 470, C1405DJR Buenos Aires, Argentina; e-mail: cappozzo@mail.retina.ar. Fax: 54-11-4982-5243; Phone: 54-11-4982-6670 (ext.159).
} 
The most important characteristics used to identify beaked whale species are: location and shape of teeth, skull morphology and head shape, and color patterns, but positive species identification often requires a combination of these data (Flower, 1878; Moore, 1968; Mead, 2002). Moreover, features of cranial morphology are only diagnostic for mature specimens (Moore, 1963; Gales et al., 2002). In several recent studies, beaked whales have been identified using molecular techniques (Henshaw et al., 1997; Dalebout et al., 1998, 2002; Gales et al., 2002; van Helden et al., 2002; Cappozzo et al., 20046; Dalebout et al., 2004). These techniques have shed new light on ziphiid species identification, since they have allowed to correctly determine the identity of cryptic species of stranded individuals (e.g. Henshaw et al., 1997; Dalebout et al., 2002; Gales et al., 2002; Dalebout et al., 2004). These studies have also made important contributions to systematics and taxonomy of beaked whales (Dalebout et al., 1998, 2002, 2004; van Helden et al., 2002). Like other ziphiid species, mesoplodonts have been identified by features of the skull, shape, size and placement of the teeth, but the anatomical similarities and the lack of fresh specimens have often led to misidentifications. Color patterns in Mesoplodon are poorly known, and the few fresh animals that do strand on beaches quickly loose details of their coloration (Pitman, 2002).

Hector's beaked whale, Mesoplodon hectori, is one of the least known ziphiid; it is found in cold temperate waters of the Southern Hemisphere, between $32^{\circ} \mathrm{S}$ and $55^{\circ} \mathrm{S}$ (Mead and Baker, 1987; Zerbini and Secchi, 2001; Pitman, 2002). In the South Atlantic Ocean, these whales are known only from a few non-fresh stranded individuals found washed ashore in Argentina, Brazil and South Africa (e.g. Ross, 1970; Goodall and Lichter7, 1988; Zerbini and Secchi, 2001).

The objective of this article is to provide information on external as well as skull and skeletal morphology, color patterns, parasites, histo-pathology and genetics of two Mesoplodon hectori stranded in Argentina in 2002.

\section{Material and Methods}

The specimens studied were two beaked whales (a male and a female) stranded alive $110 \mathrm{~km}$ away from each other, on the coast of Buenos Aires Province (see Figure 1), Argentina, in winter 2002. As different research groups analysed each specimen, the sampling protocol was not the same. Nevertheless, external and skull measurements were taken following Norris (1961) and Perrin (1975). The species' determination was attempted through cranial analysis following Moore (1963, 1968), Reyes and Molina (1998) and Dalebout et al. (2002). Ross (1984) was consulted for body and cranial morphometrics for beaked whales, in addition to specific data on $M$. hectori. Molecular analyses were used for conclusive species identification.

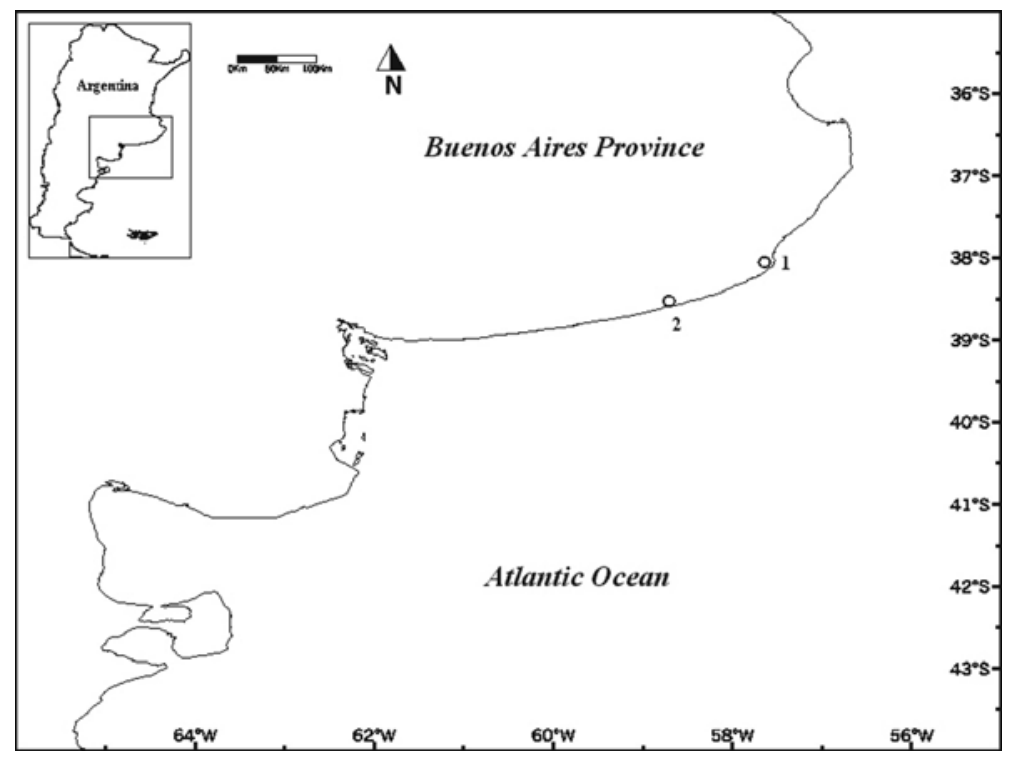

Figure 1. Area of strandings in Buenos Aires Province, Argentina. (1) Mar del Plata; (2) Quequén.

\footnotetext{
${ }^{6}$ Cappozzo, H.L., Mahler, B., Lía, V., Martínez, P. (2004) Zífidos de la Provincia de Buenos Aires y su identificación por medio del análisis de la secuencia del ADN mitocondrial. Page 22 in Abstracts. $11^{\text {th }}$ RT de Especialistas en Mamíferos Acuáticos de América del Sur and 5th Congreso SOLAMAC, Quito, Ecuador, November 2004.

${ }^{7}$ Goodall, R. N. P. and Lichter, A. A. (1988) The Hector's beak whale (Mesoplodon hectori) of Southern South America. Paper IWC/SC/40/SM 18 presented at the International Whaling Commission Scientific Committee, Auckland, May 1988, 18 pp.
} 
On 2 August 2002, a 3.94m long male beaked whale stranded alive near the Motonautical Club in Mar del Plata $\left(38^{\circ} 00^{\prime} \mathrm{S}, 57^{\circ} 33^{\prime} \mathrm{W}\right)$. Prior to stranding, the individual was seen swimming slowly in shallow waters between boats. This animal was struggling to keep stable on its normal position. It was transferred immediately to the pools of Fundación Mar del Plata Aquarium for rehabilitation, but died early the next day. The animal was dissected and the skull with its broken tip (which was caused by an attempted robbery of the teeth) was collected. The skull was deposited at Estación Hidrobiológica de Puerto Quequén for study but it is property of Fundación Mar del Plata Aquarium. Photographs were taken to describe the color patterns. Parasites found in the digestive tract (stomach and intestine) were collected. The whale did not present any external parasites or injuries.

On 3 September 2002, a 3.84m long unidentified female whale was observed swimming $30 \mathrm{~m}$ from shore near Puerto Quequén (38³7’S, 5850`W). The individual crashed against the basement rocks of the breakwater several times and finally stranded alive on the beach, dying two hours later. We arrived at the stranding site about half an hour after its death for examination. It did not present any external parasites. Local sport fishermen described that prior to the stranding, the animal was swimming towards and crashing against the breakwater. After that, it swam in circle, crashed again at the same location and ended stranding on the beach. The individual was transferred to a freezer for subsequent analysis. Measurements were taken on the right side, following Dalebout et al. (2002) for cranial and mandibular measurements. The entire axial skeleton of the female was recovered and the degree of vertebral epiphysis fusion was categorized as follows: 1 = epiphysis 0 $25 \%$ fused to the centrum (unfused); $2=$ epiphysis $25-50 \%$ fused to the centrum (partially fused); $3=50-$ $75 \%$ fused to the centrum (almost totally fused); $4=$ epiphysis $75-100 \%$ fused to the centrum (totally fused). The main vertebral measurements were taken following Lahille (1908) and Stuart and Morejohn (1980). The female beaked whale was dissected following standard protocols (Geraci and Lounsbury, 1993; Jauniaux et al., 2002): internal organs were removed, weighed, measured and then preserved at $-6^{\circ} \mathrm{C}$ for 48 hours and subsequently frozen at $-18^{\circ} \mathrm{C}$ at MACN's laboratory. Histo-pathological exams of the lungs, liver, kidneys, mesenteric lymphatic ganglia, skeletical muscle and intestine were conducted. The histo-pathological analysis was attempted taking into account the tissue characteristics rejecting those possibly altered by freezing. The digestive tract was dissected and all helminths found were removed and preserved in 70\% ethanol for posterior identification. The parasites were analysed and identified with an optical microscope and a scanning electronic microscope at the University of Valencia, Spain. The complete skeleton was cleaned and prepared for study. External morphometrics were taken with a measuring tape to the nearest $0.1 \mathrm{~cm}$. All osteological measurements were taken using a digital caliber $( \pm 0.001 \mathrm{~mm})$. The skeleton was deposited at the National Mammal Collection of the Museo Argentino de Ciencias Naturales "Bernardino Rivadavia" under the number MACN-Ma 22444.

DNA was extracted from tissue samples taken from both stranded individuals: a small amount of muscle was taken from the male, whereas small amounts of skin and liver $(<0.01 \mathrm{~g})$ were collected from the female. Total genomic DNA was isolated using proteinase $\mathrm{K}$ digestion, following standard methods (e.g. Millingan, 1998). Two fragments were amplified by polymerase chain reaction (PCR): a 500 base pair (bp) fragment of the $5^{\prime}$ end of the mitochondrial (mt) DNA control region, using M13Dlp1.5-L, 5'-TCACCCAAAGCTGRARTTCTA-3' and Dlp5-H, 5'-CCATCGWGATGTCTTATTTAAGRGGAA3' primers (Dalebout et al., 1998), and a 424 bp fragment of the $5^{\prime}$ end of cytochrome $b$, using GLUDG-L, 5'TGACTTGAARAACCAYCGTTG-3' and CB2-H, 5'CCCTCAGAATGATATTTGTCCTCA-3' primers (Palumbi, 1996). Each PCR had a reaction volume of $100 \mu 1$ and contained $20 \mu \mathrm{l}$ of $5 \mathrm{ng} / \mu \mathrm{l} \mathrm{DNA}, 5 \mu \mathrm{l}$ of $50 \mathrm{mM} \mathrm{MgCl}_{2^{\prime}}$ $5 \mu \mathrm{l}$ of $10 \mathrm{X}$ reaction buffer, $0.5 \mu \mathrm{l}$ of $20 \mathrm{mM}$ premixed deoxynucleotide triphosphates, $5 \mu 1$ of $10 \mathrm{mg} / \mathrm{ml}$ bovine serum albumin, 1.25 units of Taq polymerase (Invitrogen, Life Technologies, Renfrew, United Kingdom), $4 \mu 1$ of $5 \mu \mathrm{M}$ oligonucleotide primers and water to reach the final volume reaction. PCR products were purified with the QIAQuick gel extraction Kit (QIAGEN Inc., Valencia, CA, USA), and sequenced in a PEBioSystems automated 377 DNA sequencer. Representative tissue samples of both individuals are stored at the Museo Argentino de Ciencias Naturales. Sequences have been deposited in GenBank (Access numbers: AY228107 to AY228110). The resulting sequences (mtDNA control region: male $475 \mathrm{bp}$, female $450 \mathrm{bp}$; cytochrome $b$ : male $439 \mathrm{bp}$, female $440 \mathrm{bp}$ ) were compared to 42 reference sequences belonging to 21 ziphiid species at Witness for the Whales web page (www.dna-surveillance.auckland.ac.nz), University of Auckland.

\section{RESULTS}

\section{Species identification}

The specimens stranded at Mar del Plata and Quequén coasts were identified as Hector's beaked whales, Mesoplodon hectori, based on features of the skull, and shape, size and placement of the teeth. Species identity was later confirmed based on mtDNA sequences.

\section{Sexual dimorphism in color pattern}

The male and the female presented different color patterns (Figure 2). The male was dark gray, almost black dorsally, with slightly lighter ventral zone. 
It presented scars throughout its body. Teeth marks, mainly on its back and flanks were probably a result of intra-specific male-to-male interactions. Ventral oval white scars were possibly caused by cookiecutter shark (Isistius sp.) bites. The female was light gray dorsally and white in the ventral area (Figure
2). It also presented several scars on its body, flippers, dorsal fin and tail, probably produced by rocks during the crashes and the stranding or during interactions with other individuals at sea. External measurements of both individuals are shown in Table 1.

a

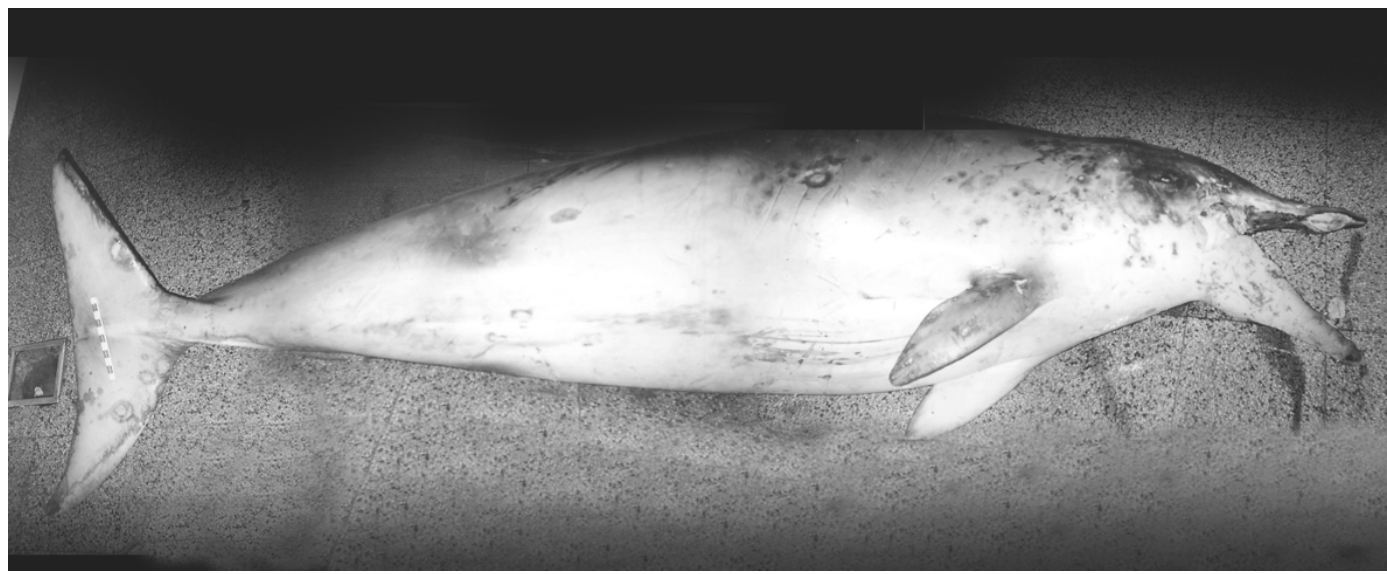

b

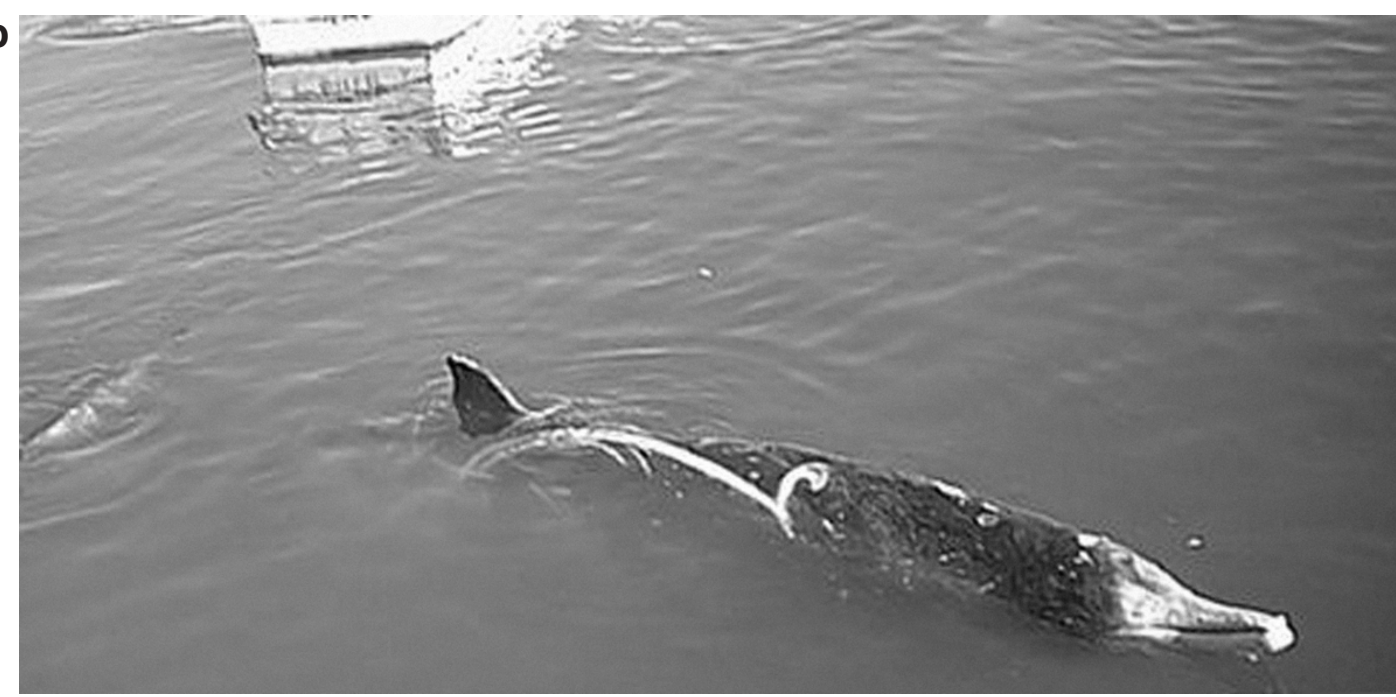

C

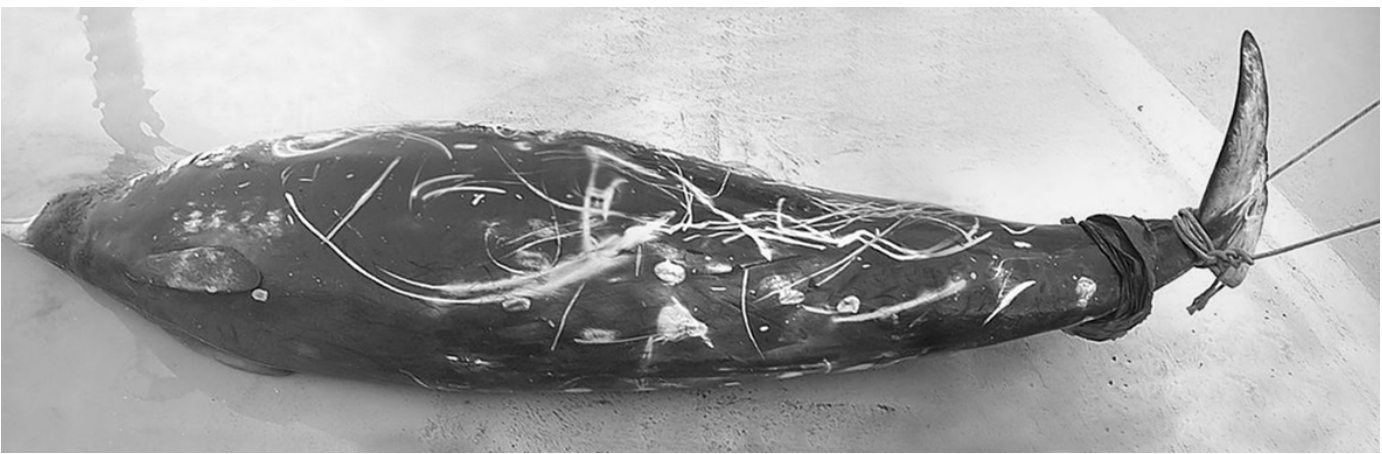

Figure 2. External appareance of Mesoplodon hectori specimens from Argentina: (a) female of Quequén, (b) alive male of Mar del Plata, (c) male of Mar del Plata. 


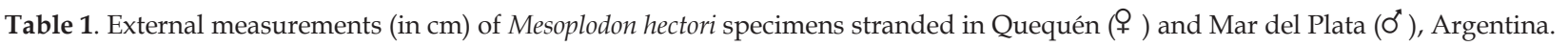

\begin{tabular}{|c|c|c|c|}
\hline & & QUEQUÉN & MAR DEL Plata \\
\hline 1. & Total length & 384.0 & 394.0 \\
\hline 2. & Snout to center of blowhole & 47.0 & 49.0 \\
\hline 3. & Snout to center of eye & 49.5 & 51.0 \\
\hline 4. & Snout to angle of mouth & 31.0 & 39.0 \\
\hline 5. & Snout to anterior insertion of flipper & 82.5 & 93.0 \\
\hline 6. & Snout to anus & 268.0 & 280.0 \\
\hline 7. & Snout to tip of dorsal fin & 251.0 & 231.0 \\
\hline 8. & Girth at axilla & 180.0 & - \\
\hline 9. & Maximum girth & 186.0 & - \\
\hline 10. & Girth at anus & 185.0 & - \\
\hline 11. & Girth at cervical vertebrae & 126.0 & - \\
\hline 12. & Girth at insertion of caudal fin & 48.0 & - \\
\hline 13. & Blowhole length (parallel to body axis) & 7.5 & - \\
\hline 14. & Distance from genital slit to anus & 2.0 & - \\
\hline 15. & Number of mammary slits & 2.0 & - \\
\hline 16. & Lenght of mammary slits & 5.0 & - \\
\hline 17. & Lenght of genital slits & 3.0 & - \\
\hline 18. & Flipper length, anterior & 41.0 & 45.0 \\
\hline 19. & Flipper length, posterior & 27.0 & 32.0 \\
\hline 20. & Flipper width, maximum & 12.5 & 14.5 \\
\hline 21. & Fluke span & 95.0 & 109.0 \\
\hline 22. & Fluke width & 36.0 & - \\
\hline 23. & Dorsal fin height & 16.0 & 18.0 \\
\hline
\end{tabular}

\section{Skull}

Male (Figures 3 to 5) and female (Figures 6 and 7) skulls allowed the species identification. Measurements obtained from both specimens are shown in Table 2. The skull has premaxillae as the most anterior structures on the vertex. The combined nasals anterodorsal surface presents a central depression, so the lateral margin of nasals is the most anterior on vertex. In frontal view, a plane connects the highest points of maxillary crests through the mesethmoides. The breadth of maxillary foramen is smaller than the least distance between foraminas. The span of premaxillary crests is less than the span of premaxillae at the anterior margin of the superior nares. The extension of right premaxilla posterior to right nasal on vertex is less than $70 \%$ of dorsal surface nasal length for both whales. This proportion is $42.52 \%$ and $20.55 \%$ for the female and male specimens, respectively. The antorbital tubercle is exclusively formed by the maxillar. Teeth are reduced to a single triangular, laterally compressed pair located at the tip of the mandible (Figures 5 and 7). The mandibular symphysis was fused at approximately $37 \%$ of the mandible length. In both individuals, the neurocranium is inflated and the maxillaries are prominent in frontal view in each side of the synvertex. The ventral lateral outline of the rami is concave over the length of the symphysis. The broken female's rostrum precluded taking some measurements. Nonetheless, the broken condylobasal length and broken mandible length of the female's skull were measured at $456 \mathrm{~mm}$ and $416 \mathrm{~mm}$, respectively (Figure 7). The hyoid bones were fused and the greatest width of basi-thyrohyal complex (Stuart and Morejohn, 1980) was of 151mm.

\section{Skeleton}

The entire axial skeleton was recovered. The vertebral formula was C7 + T10 + L11 + Ca21 $=49$. The degree of fusion of the vertebral epiphyses and the main measurements of each vertebra are shown in Table 3. Sixty-eight percent of the vertebral epiphyses were unfused to their centra (fusion degree \#1), and 32\% were almost totally fused (fusion degree \#3). A total of nine chevron bones were found, the first one being positioned between the first and second caudal vertebrae. The sternum was unfused and articulated to five of the 12 ribs on each side.

\section{Histo-pathological exam}

A histo-pathological study was conducted for the lung, liver, kidney, mesenteric lymphatic node, muscle and intestines of the female specimen. 
The observed tissues presented some damage as a consequence of the freeze-thaw procedure, and postmortem changes, as the loss of the tissue architecture not associated with inflammation, gas or hemolytic processes. Despite the damaged tissue, the following relevant findings could be recorded: the lungs showed atelectasy or alveolus congestion, with thickening of the alveolar partitions by fibrosis. Diffuse infiltration of hypertrophy macrophages was observed. Basophile structure with oblongum shape, surrounded by connective tissue and mononuclear cells deformed with few eosinophile cells was noted. The liver showed congestion and infiltration of mononuclear cells in the porta spaces was observed, as well as presence of gas bubbles. The kidney showed post-mortem autolysis. The skeletal muscle showed isolated cysts of Sarcocystis $\mathrm{sp}$. The diagnosis suggested that the lung lesions are related with parasitic damage and pneumonia or chronic infection. It is important to highlight that Sarcocystiasis was found even when this was not the cause of death. The weights of selected internal organs of the female $M$. hectori specimen and blubber depth at different areas are shown in Table 4. The male organs were not available for histo-pathological studies. a

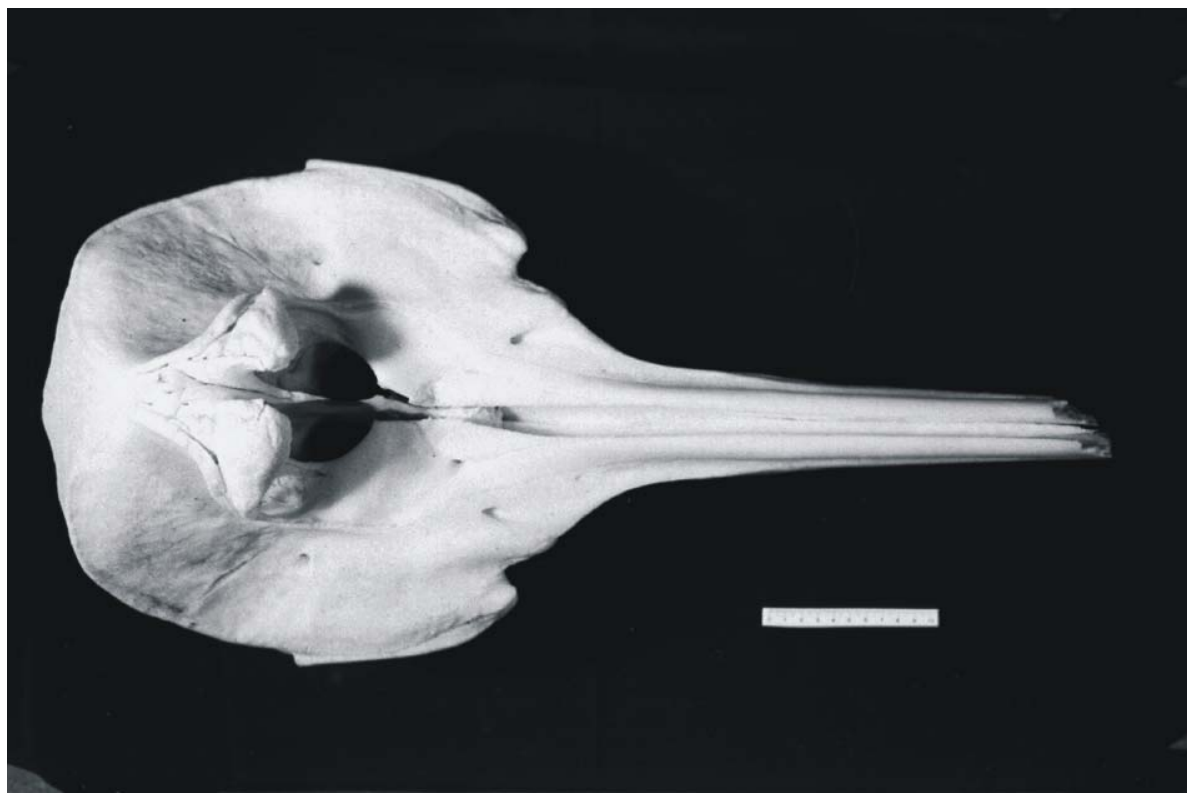

b

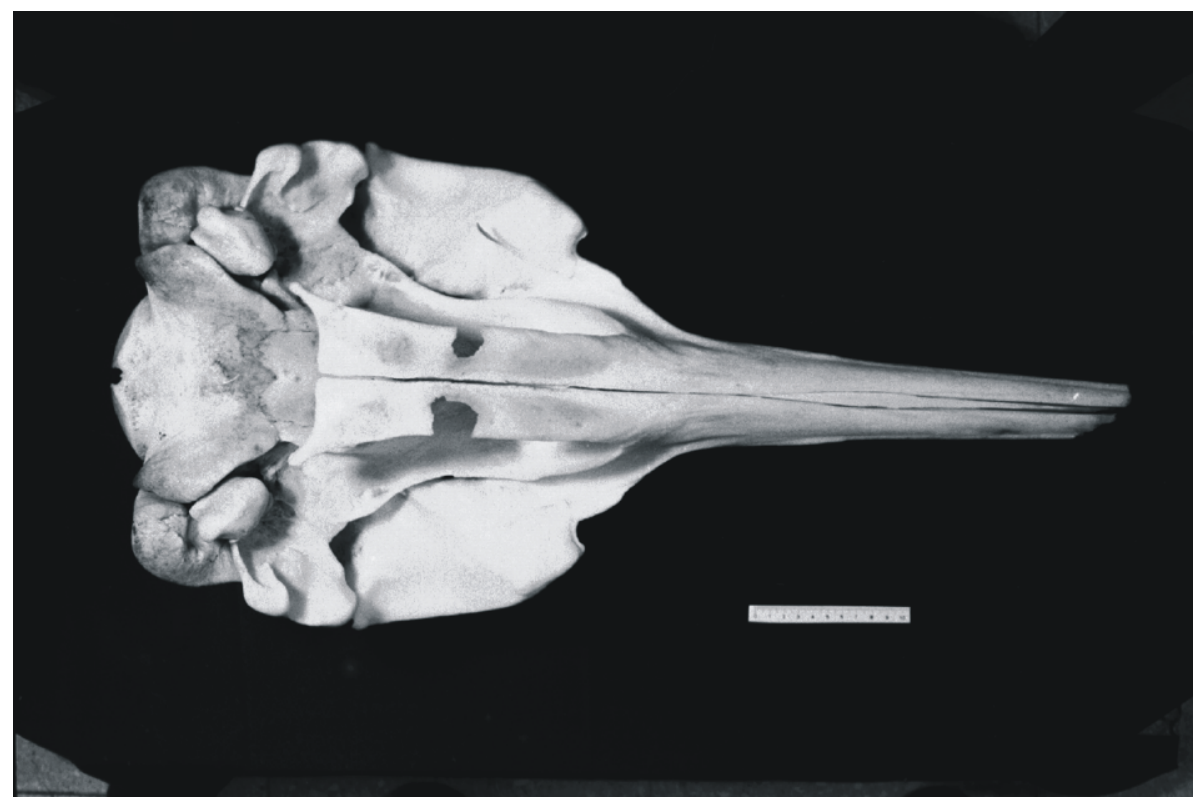

Figure 3. Skull of a male Mesoplodon hectori stranded in Mar del Plata, Argentina: (a) dorsal view, (b) ventral view. 


\section{Stomach}

The female's stomach weighed $2.45 \mathrm{~kg}$ and was empty. It presented four externally well defined chambers. As in other genera of beaked whales, the forestomach was lacking and the first and second chamber corresponded to the compartments of the main stomach as described for this genus by Mead (1993). The major chamber, the proximal main stomach, was connected with the esophagus and presented many internal folds. The main color of the epithelium was pink. Dozens of nematodes were concentrated in the posterior region of this chamber. The second chamber, the distal main stomach compartment, opened blindly off the proximal compartment and the connecting chambers communicated with the proximal chamber, according to Mead (1993). The epithelium of the distal main stomach was smooth pink without folds. This chamber was small, but larger than the last two. The epithelium of the third chamber, the connecting stomachs, presented longer and larger folds when compared with the main stomach, and the color was gray. Its external surface was hard. The fourth chamber, the pyloric stomach, was connected with the initial portion of the small intestine. Dozens of nematodes were found in all but the connecting chamber.

a

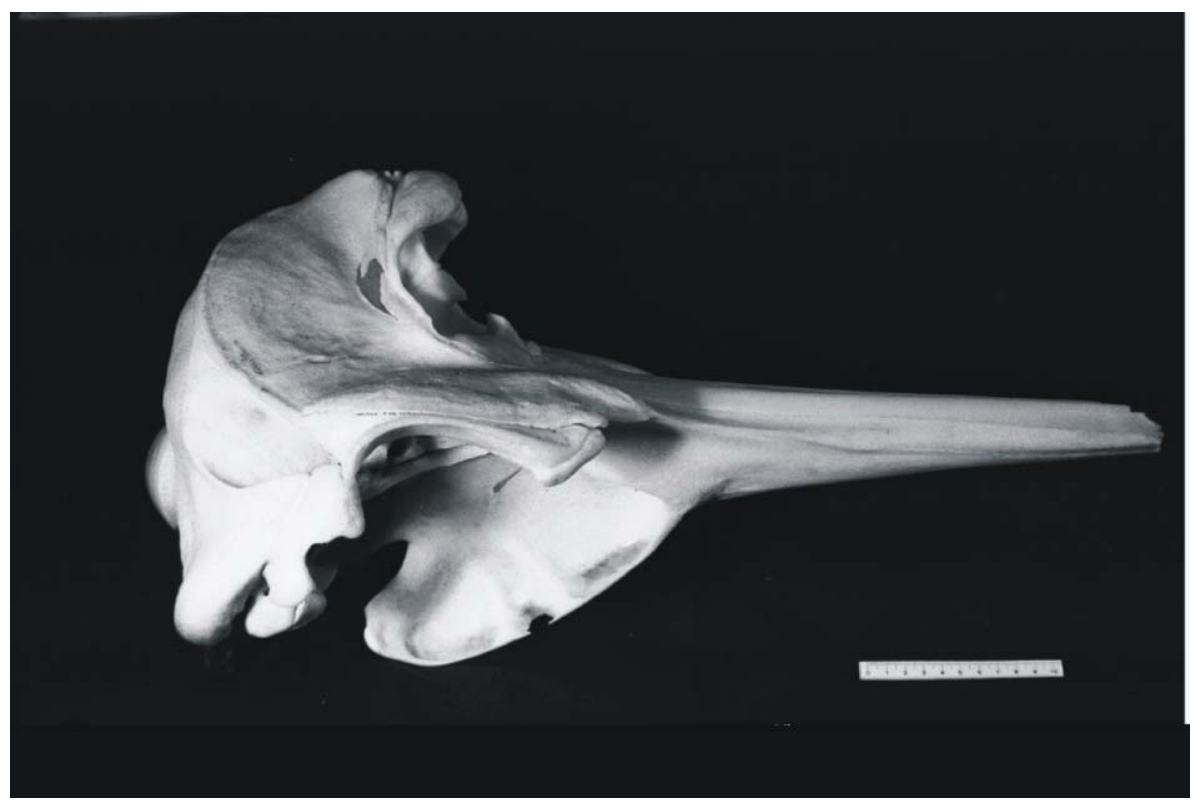

b

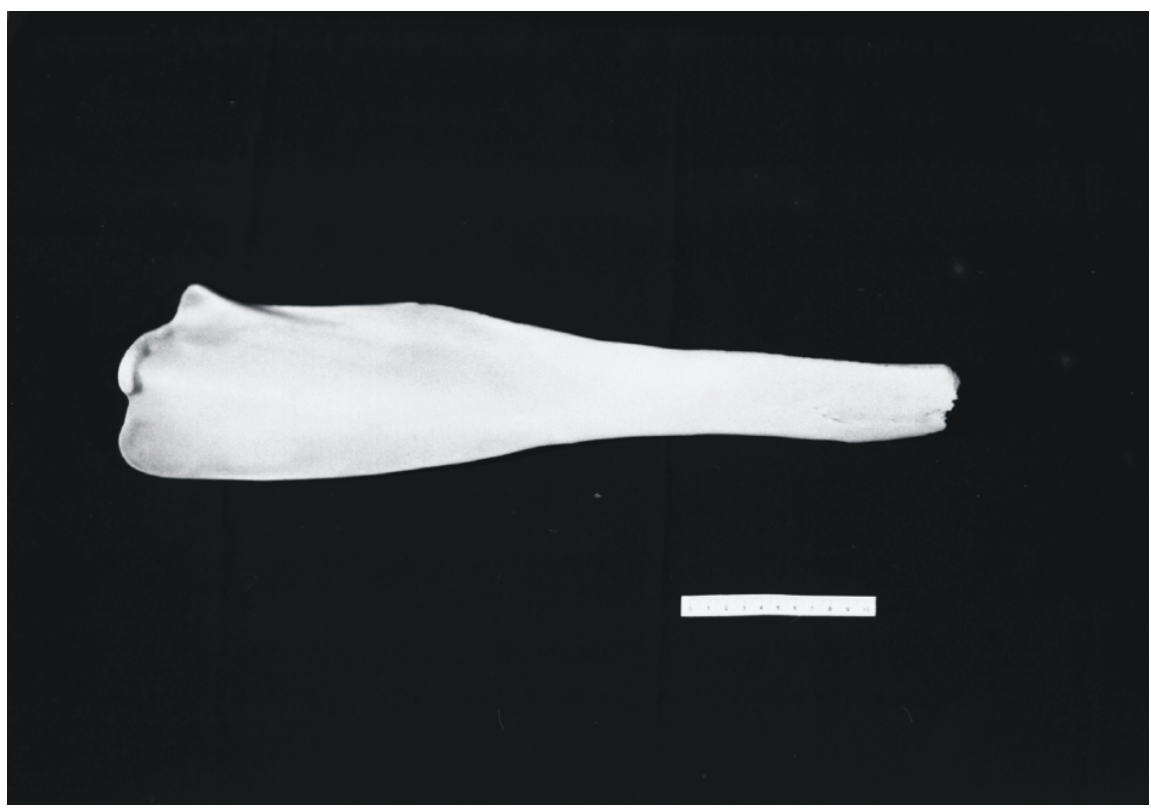

Figure 4. Skull and madible of a male Mesoplodon hectori stranded in Mar del Plata, Argentina: (a) lateral view of skull, (b) left mandible. 
This chamber presented a large amount of undetermined crystalline lenses (but not associated to cephalopods beaks) and a small rock. Small crystalline lenses were also found in the main and pyloric stomachs. The gastric fluid was orange and it was also seen in some segments of the intestines. The stomach of the male individual was empty.

\section{Parasites}

The female's intestine was $18.5 \mathrm{~m}$ long. All parasites were removed from it. A preliminary analysis confirmed the presence of Tetrabothrius sp. (Cestoda), Bolbosoma sp. (Acanthocephala) and Anisakis sp. (Nematoda). A few stomach fluke (Braunina cordiformis) individuals (Trematoda) were collected from the male's stomach. The helminths found are the first fresh parasites for this species and will require future definitive identification. All nematodes were at larval (L4) stage of Anisakis spp.

a

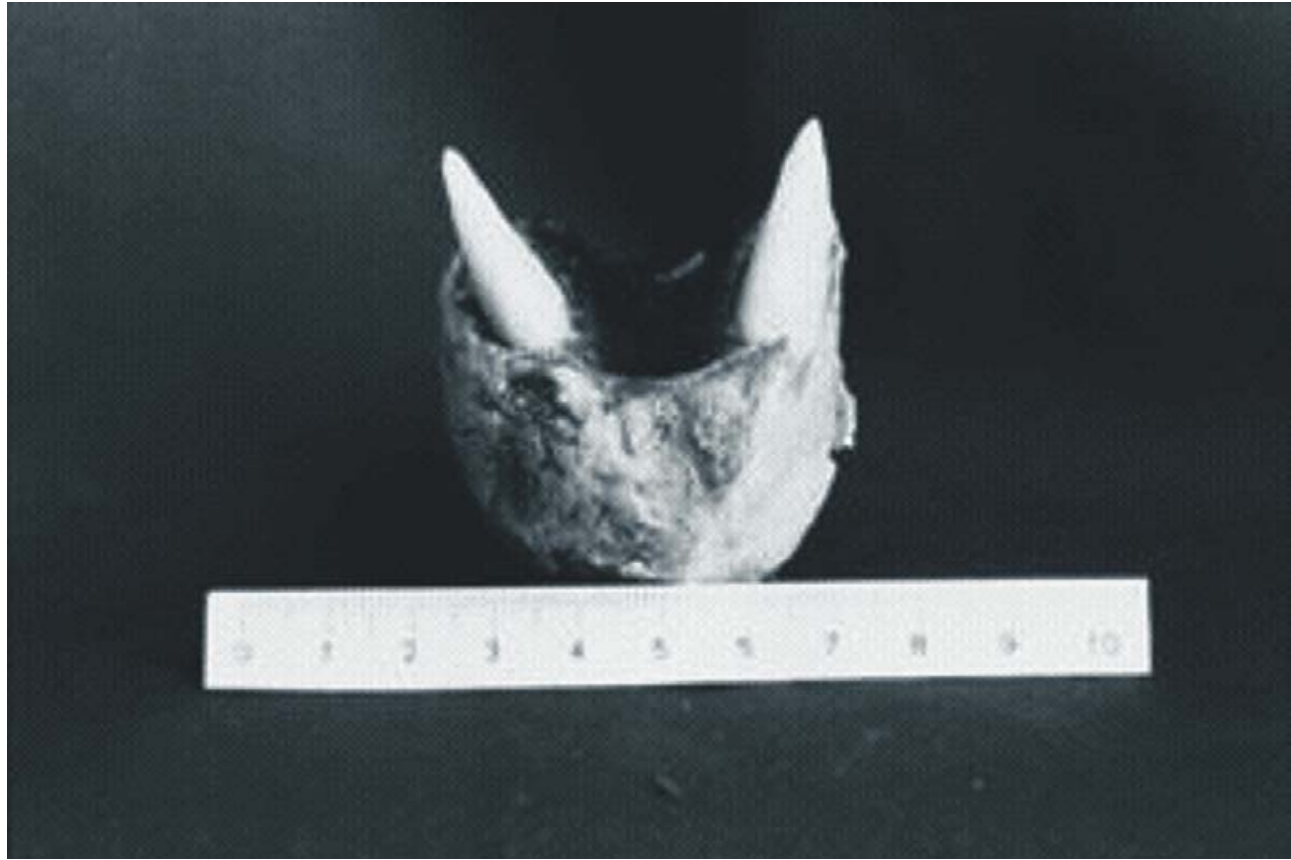

b

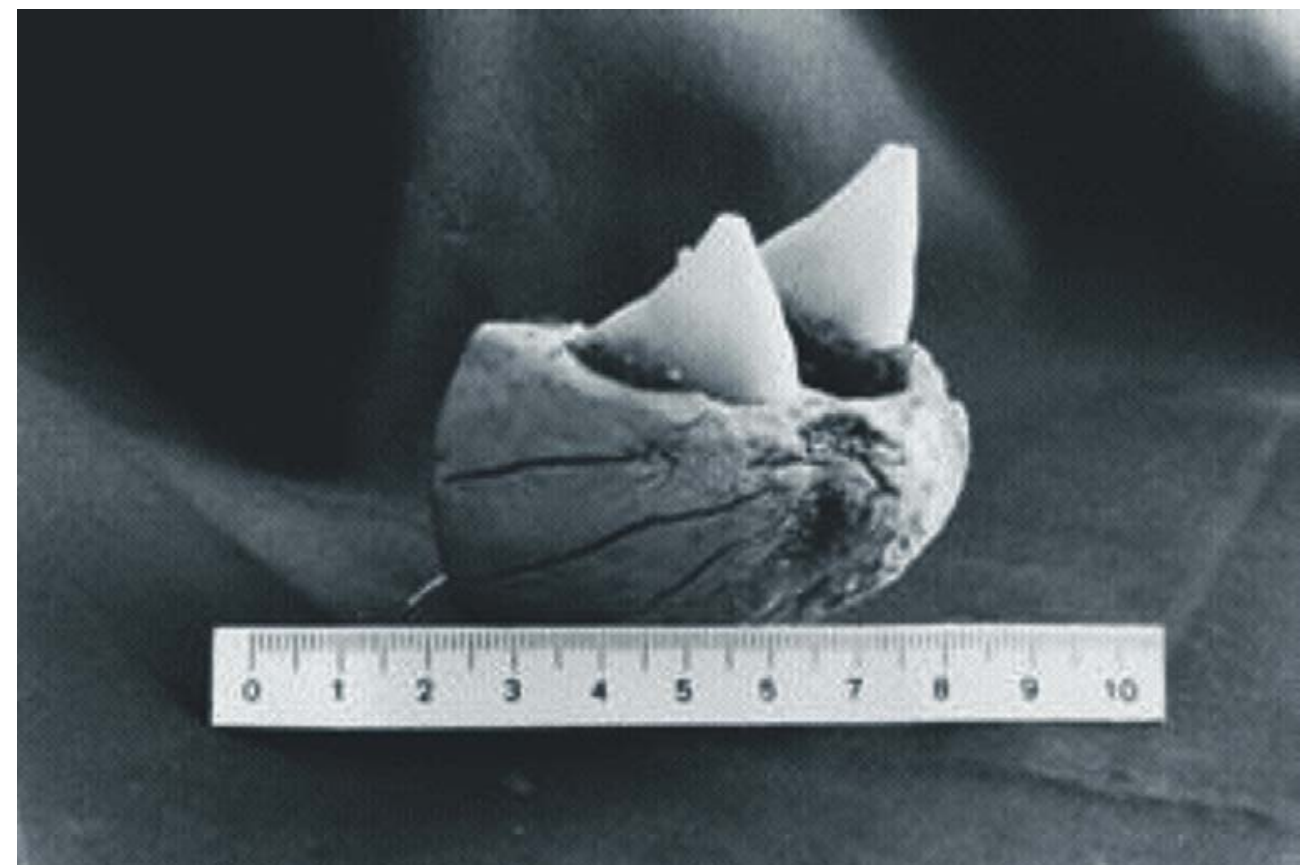

Figure 5. Teeth of a male Mesoplodon hectori stranded in Mar del Plata, Argentina: (a) frontal view, (b) lateral view.. 


\section{Analyses of mtDNA Sequences}

Phylogenetic analyses of mtDNA control region and cytochrome $b$ sequences at Witness for the Whales web page have allowed unambiguous identification of both stranded beaked whales as Hector's beaked whale, Mesoplodon hectori (Figure 8). In the case of the male specimen, sequence divergence with one Australian individual (AF036220) was 0\%, indicating that they shared the same haplotype. Sequence divergence between both individuals was $1.23 \%$ and sequence divergence of both individuals with two Australian M. hectori (AY028313) did not exceed $1.25 \%$ (Table 5). Comparisons of cytochrome $b$ sequences between the male and the female showed a very low divergence. The divergence was high when sequences were compared with other ziphiids (Table 6).

a

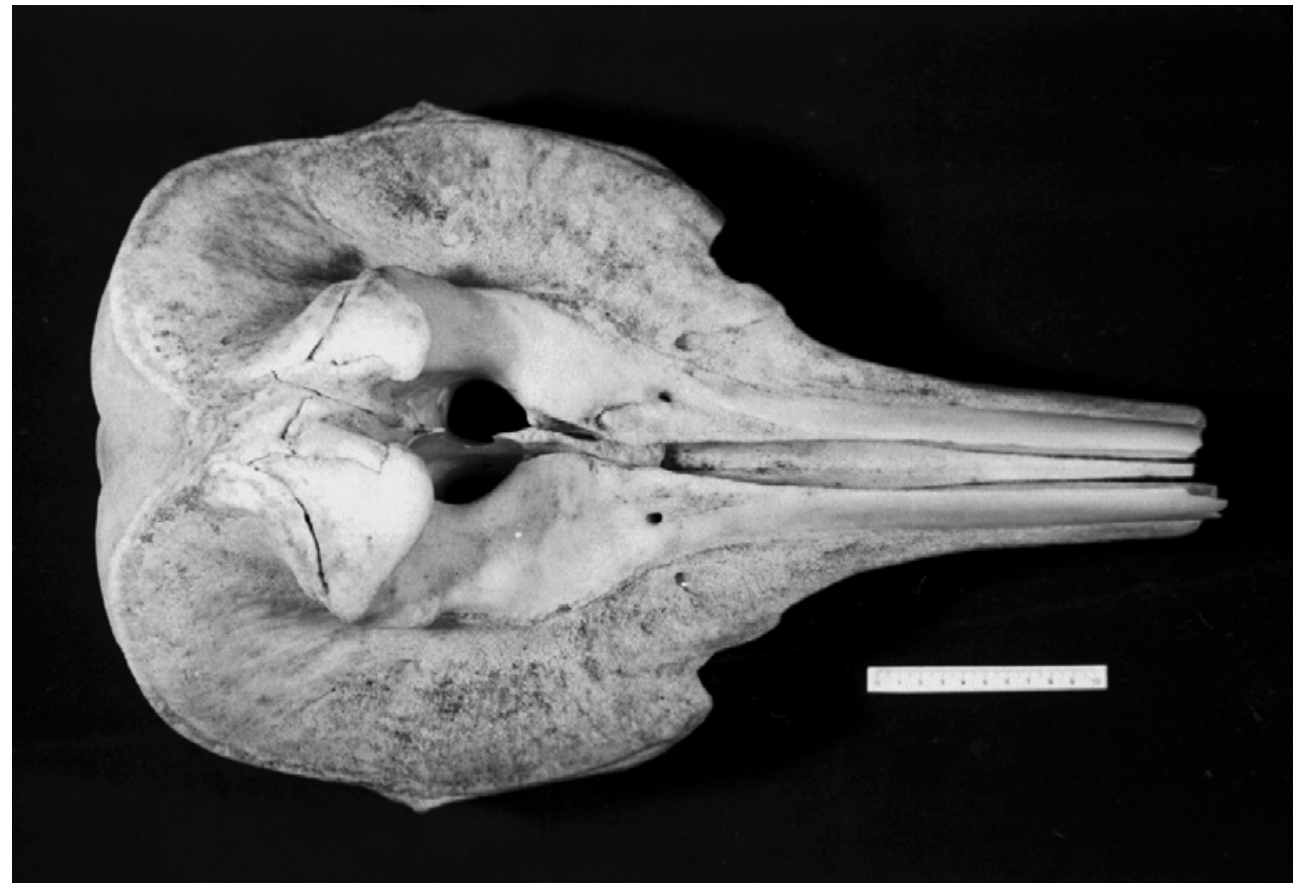

b

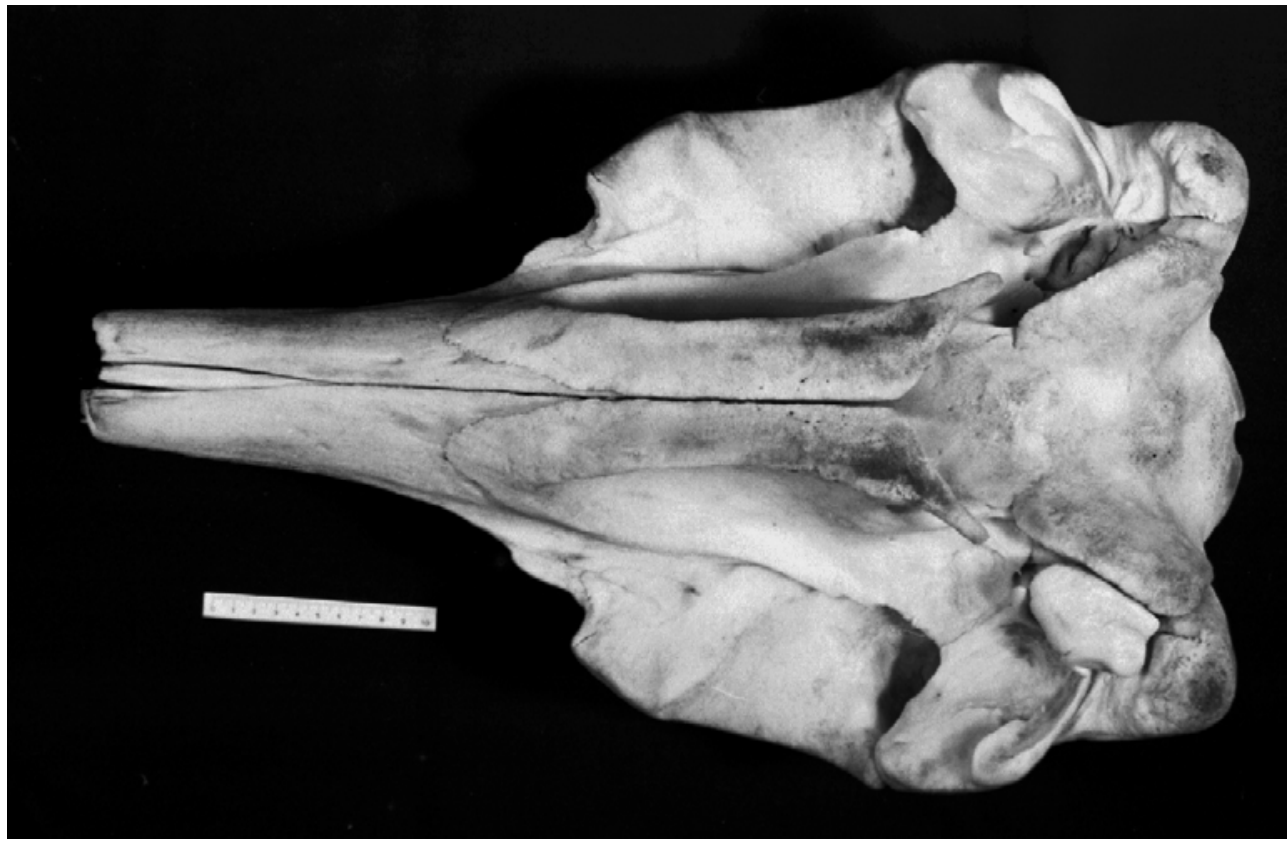

Figure 6. Skull of a female Mesoplodon hectori stranded in Quequén, Argentina: (a) dorsal view, (b) ventral view. 


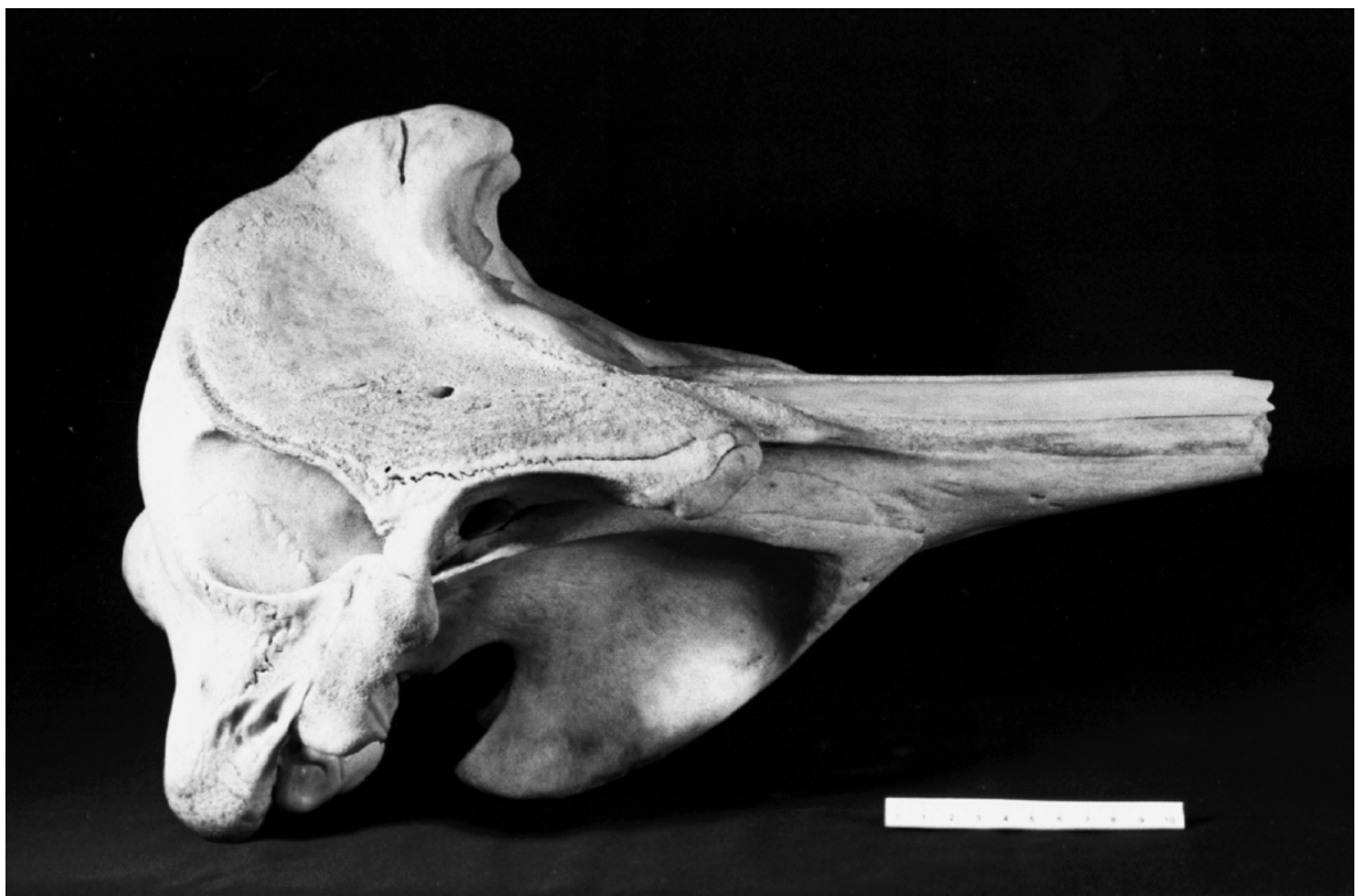

b

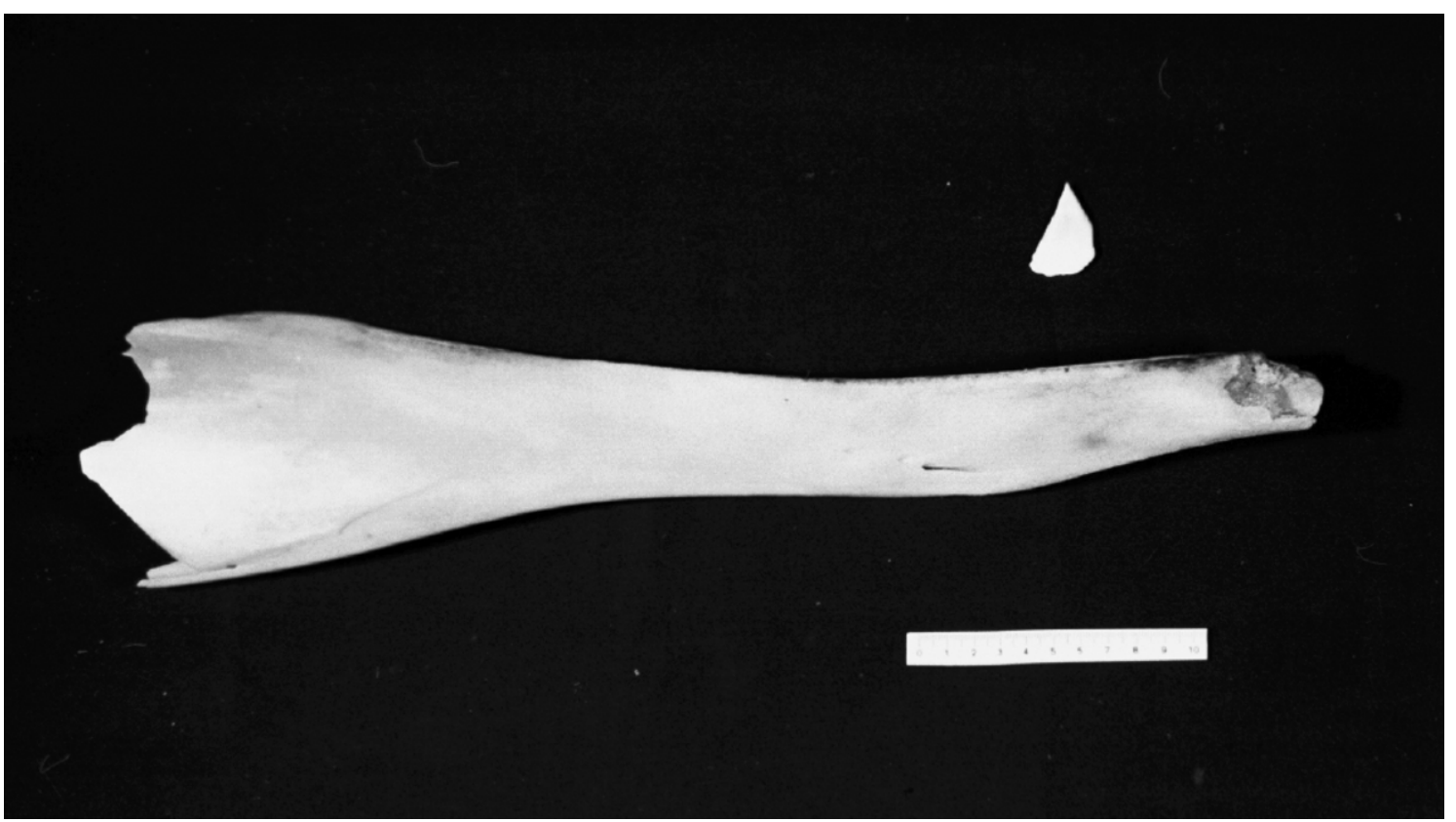

Figure 7. Skull and madible of a female Mesoplodon hectori stranded in Quequén, Argentina: (a) lateral view of skull, (b) left mandible and tooth.. 
Table 2. Cranial and mandible measurements (in $\mathrm{mm}$ ) of Mesoplodon hectori specimens stranded in Quequén (오 ) and Mar del Plata $\left(0^{\prime \prime}\right)$, Argentina.

\begin{tabular}{|c|c|c|c|c|c|c|}
\hline & & QUEQ & UÉN & & R DEL Pl & ATA \\
\hline & CRAnial Measurements & $\mathrm{mm}$ & $\%$ ZGW & $\mathrm{mm}$ & $\% \mathrm{CBL}$ & $\%$ ZGW \\
\hline 1. & Condylobasal length (CBL) & - & - & 617.00 & 100.00 & 222.74 \\
\hline 2. & Tip rostrum to posterior extension maxillary plate & - & - & 572.00 & 92.71 & 206.50 \\
\hline 3. & Tip rostrum to anterior margin superior nares & - & - & 412.00 & 66.77 & 148.74 \\
\hline 4. & Tip rostrum to anterior point maxillary crest & - & - & 312.00 & 50.57 & 112.64 \\
\hline 5. & $\begin{array}{l}\text { Tip rostrum to posterior extension premaxilla } \\
\text { on lateral tip of right premaxillary crest }\end{array}$ & - & - & 473.00 & 76.66 & 170.76 \\
\hline 6. & Tip rostrum to posterior extension temporal fossa & - & - & 580.00 & 94.00 & 209.39 \\
\hline 7. & Tip rostrum to apices of antorbital notches & - & - & 346.00 & 56.08 & 124.91 \\
\hline 8. & Breadth skull across orbital centres & 254.00 & 90.39 & 270.00 & 43.76 & 97.47 \\
\hline 9. & Breadth skull across postorbital process frontals & 286.00 & 101.78 & 286.00 & 46.35 & 103.25 \\
\hline 10. & Breadth skull across zygomatic processes squamosals (ZGW) & 281.00 & 100.00 & 277.00 & 44.89 & 100.00 \\
\hline 11. & Least breadth skull across posterior margins temporal fossae & 205.00 & 72.95 & 201.00 & 32.58 & 72.56 \\
\hline 12. & Greatest breadth skull across exoccipitals & 237.00 & 84.34 & 234.00 & 37.93 & 84.48 \\
\hline 13. & Greatest span occipital condyles & 91.60 & 32.60 & 99.36 & 16.10 & 35.87 \\
\hline 14. & Greatest width of an occipital condyle & 61.90 & 22.03 & 69.67 & 11.29 & 25.15 \\
\hline 15. & Greatest length of an occipital condyle & 33.00 & 11.74 & 39.07 & 6.33 & 14.10 \\
\hline 16. & Greatest breadth foramen magnum & 38.50 & 13.70 & 38.23 & 6.20 & 13.80 \\
\hline 17. & Greatest length of right nasal on vertex & 36.45 & 12.97 & 44.08 & 7.14 & 15.91 \\
\hline 18. & Length nasal suture & 47.00 & 16.73 & 49.21 & 7.98 & 17.77 \\
\hline 19. & Extension right premaxilla posterior to right nasal on vertex & 15.50 & 5.52 & 9.06 & 1.47 & 3.27 \\
\hline 20. & Greatest breadth nasals on vertex & 41.20 & 14.66 & 31.01 & 5.03 & 11.19 \\
\hline 21. & Least distance between anterior prominences of the synvertex & 22.40 & 7.97 & 16.58 & 2.69 & 5.99 \\
\hline 22. & Greatest span premaxillary crests & 121.50 & 43.24 & 113.52 & 18.40 & 40.98 \\
\hline 23. & Greatest transverse width of superior nares & 49.65 & 17.67 & 65.43 & 10.60 & 23.62 \\
\hline 24. & Width rostrum in apices of antorbital notches & 157.00 & 55.87 & 153.00 & 24.80 & 55.23 \\
\hline 25. & Least distance between main maxillary foramina & 84.35 & 30.02 & 89.00 & 14.42 & 32.13 \\
\hline 26. & Least distance between premaxillary foramina & 43.20 & 15.37 & 46.62 & 7.56 & 16.83 \\
\hline 27. & $\begin{array}{l}\text { Distance posterior margin of left maxillary foramina } \\
\text { to anterior margin maxillary prominence }\end{array}$ & 116.40 & 41.42 & 134.01 & 21.72 & 48.38 \\
\hline 28. & Width rostrum at mid-length of rostrum & - & - & 46.60 & 7.55 & 16.82 \\
\hline 29. & Width premaxillae at mid-length of rostrum & - & - & 34.59 & 5.61 & 12.49 \\
\hline 30. & Height of skull & 277.00 & 98.58 & 282.00 & 45.71 & 101.81 \\
\hline 31. & Greatest length of temporal fossa & 91.80 & 32.67 & 101.56 & 16.46 & 36.66 \\
\hline 32. & Width of temporal fossa & 80.40 & 28.61 & 100.76 & 16.33 & 36.38 \\
\hline 33. & Tip rostrum to posterior extension of maxilla between pterygoids & - & - & 340.00 & 55.11 & 122.74 \\
\hline 34. & Tip rostrum to anterior extension of pterygoid sinus & - & - & 370.00 & 59.97 & 133.57 \\
\hline 35. & Tip rostrum to most anterior extension of pterygoids & - & - & 274.00 & 44.41 & 98.92 \\
\hline 36. & Tip rostrum to posterior margin of pterygoid mid-line & - & - & 477.00 & 77.31 & 172.20 \\
\hline 37. & Tip rostrum to posterior extension of wing of pterygoid & - & - & 485.00 & 78.61 & 175.09 \\
\hline 38. & Length of vomer visible at surface of palate & 143.00 & 50.89 & 231.13 & 37.46 & 83.44 \\
\hline 39. & Basilar height of skull & 31.50 & 11.21 & 32.24 & 5.23 & 11.64 \\
\hline 40. & Height of rostrum at mid-length of rostrum & - & - & 50.99 & 0.83 & 18.41 \\
\hline 41. & Greatest height foramen magnum & 40.30 & 14.34 & 42.57 & 6.90 & 15.37 \\
\hline 42. & Superior height of skull & 148.00 & 52.67 & 172.28 & 2.79 & 62.19 \\
\hline 43. & Greatest height of temporal fossa & 52.40 & 18.65 & 52.07 & 8.44 & 18.80 \\
\hline 44. & Distance frontal crest to occipital condyle base & 244.00 & 86.83 & 232.00 & 3.75 & 83.75 \\
\hline 45. & Height of basioccipital processes & 71.45 & 25.43 & 32.42 & 5.25 & 11.70 \\
\hline 46. & Greatest lenght of left pterygoid & 208.00 & 74.02 & 224.00 & 3.63 & 80.87 \\
\hline & Extension right premaxilla anterior to right nasal on vertex & 18.80 & 6.69 & 14.73 & 2.39 & 5.32 \\
\hline 48. & Greatest length of premaxilla on vertex & 62.80 & 22.35 & 65.86 & 1.07 & 23.78 \\
\hline & Greatest breadth frontals on vertex & 33.35 & 11.87 & 27.81 & 4.51 & 10.04 \\
\hline & Greatest breadth maxillary crests on vertex & 117.45 & 41.80 & 109.00 & 1.76 & 39.35 \\
\hline
\end{tabular}




\begin{tabular}{|c|c|c|c|c|c|c|}
\hline & \multirow[b]{2}{*}{ CRANIAL MEASUREMENTS } & \multicolumn{2}{|c|}{ QUEQUÉN } & \multicolumn{3}{|c|}{ MAR DEL PLATA } \\
\hline & & $\mathrm{mm}$ & $\% \mathrm{ZGW}$ & $\mathrm{mm}$ & $\% \mathrm{CBL}$ & $\%$ ZGW \\
\hline & MANDIBLE MEASUREMENT & & & & & \\
\hline 51. & Mandibular length & - & - & 465.00 & 75.36 & 167.87 \\
\hline 52. & Length from posterior extension of symphysis to condyles & - & - & 385.00 & 62.40 & 138.99 \\
\hline 53. & Length posterior margin of alveolus to condyles & - & - & 465.00 & 75.36 & 167.87 \\
\hline 54. & Greatest length of symphysis & - & - & 85.11 & 13.79 & 30.73 \\
\hline 55. & Greatest height of mandible at coronoid processes & - & - & 109.00 & 17.67 & 39.35 \\
\hline 56. & Outside height of mandible at midlength of alveolus & - & - & 32.33 & 5.24 & 11.67 \\
\hline 57. & Length of alveolus & - & - & 28.87 & 4.68 & 10.42 \\
\hline 58. & Width of alveolus & - & - & 9.27 & 1.50 & 3.35 \\
\hline 59. & Tip of mandible to alveolus & - & - & 15.03 & 2.44 & 5.43 \\
\hline 60. & Greatest tooth length & 32.30 & 11.49 & 22.88 & 3.71 & 8.26 \\
\hline 61. & Greatest tooth width & 24.50 & 8.72 & 26.99 & 4.37 & 9.74 \\
\hline 62. & Greatest tooth breadth & 4.40 & 1.57 & 8.62 & 1.40 & 3.11 \\
\hline 63. & Height of crown of tooth & 11.60 & 4.13 & 22.88 & 3.71 & 8.26 \\
\hline 64. & Lenght of dental foramen & - & - & 167.06 & 27.08 & 60.31 \\
\hline
\end{tabular}

\section{Discussion}

The stranding of two individuals of the same species only three weeks and $110 \mathrm{~km}$ apart from each other could be considered as a unique biological event, as both stranding events occurred within the same general area and time frame. Beaked whales do not typically strand in pairs, except in mother-calf cases (e.g. Lichter, 1986). The species is known mainly from stranded animals. In the Southern Hemisphere they have been reported from strandings in Argentina (Lichter, 1986), Brazil (Zerbini and Secchi, 2001), Chile (Sielfeld, 1979), South Africa (Ross, 1970; 1984), New Zealand (Baker et al., 2001), and southern Australia (Gales et al., 2002). Worldwide only 28 specimens of $M$. hectori have been recorded to date (Gales et al., 2002; this study), therefore, available data for this species are scarce. Despite systematic and non-systematic sigthing and stranding surveys over the past 30 years, there are only few records of this species along the western South Atlantic coast (Goodall, 1978; Lichter, 1986; Lichter and Goodall, 1988; Zerbini and Secchi, 2001). Records of M. hectori on the Pacific coast of South America are even more rare (Sielfeld, 1979). The finding and description of these two individuals further contribute to the knowledge about Hector's beaked whale, particularly as data from fresh specimens are provided.

Hector's beaked whale's total length is less than 4.5 meters. It is probably the second smallest ziphiid, after the pygmy beaked whale, M. peruvianus (Baker et al., 2001; Pitman, 2002). The total lengths of the two individuals reported here are close to the maximum reported length reported for male $(4.3 \mathrm{~m})$ and female $(4.4 \mathrm{~m})$ Hector's beaked whales (Mead, 1989; Pitman, 2002). Furthermore, two females of similar sizes $(4.15 \mathrm{~m}$ and $4.0 \mathrm{~m}$ long) accompanied by two calves $(1.9 \mathrm{~m}$ and $2.02 \mathrm{~m}$ long, respectively) found at Claromecó (Buenos Aires Province, Argentina) in 1985 (Lichter, 1986), indicate that both animals recorded here were adults. Most specimens of this species have been found in advanced decomposition. Goodall (1978) reported a young animal with a complete $2.81 \mathrm{~m}$ long skeleton in which none of the vertebrae were fused and the two well-developed teeth presented indicated that it was a male. Zerbini and Secchi (2001) recorded a specimen in which the skull and post-cranial skeleton measured $2.36 \mathrm{~m}$ on a straight line. The testes and ovaries of the specimens in this study were lost during necropsy, thus precluding histological studies for determining sexual maturity.

The coloration was different between the two individuals, indicating possible gender-related variation in color pattern of this species. The male's color pattern was different from the description made by Mead (1981), but a recent study assigned that specimen to another species of the genus (M. perrini, Dalebout et al., 2002). It was in fact different from any previous description of the species (Gales et al., 2002), probably a consequence of the scarcity of available information on color patterns and of potential ontogenetical variation in the species.

No identifiable food items were found in the stomach of either individual. Only remains of invertebrates and some crystallines of undetermined species, probably from teleosts, were found, preventing us from gaining insights into the species' feeding ecology. The absence of food in the stomach is probably due to a long fasting period before stranding. Nonetheless, parasites removed from the male's stomach were different from those found in the female's, suggesting different prey items as intermediary host or some degree of individual variability in prey preferences, which is difficult to assess with such small sample sizes. Our description of the stomach is coherent with the taxonomic model proposed by Mead (1993) for the anatomy of Mesoplodon. 
Table 3. Vertebral measurements (in mm) and epiphysis fusion degree of a female Mesoplodon hectori stranded at Quequén, Argentina.

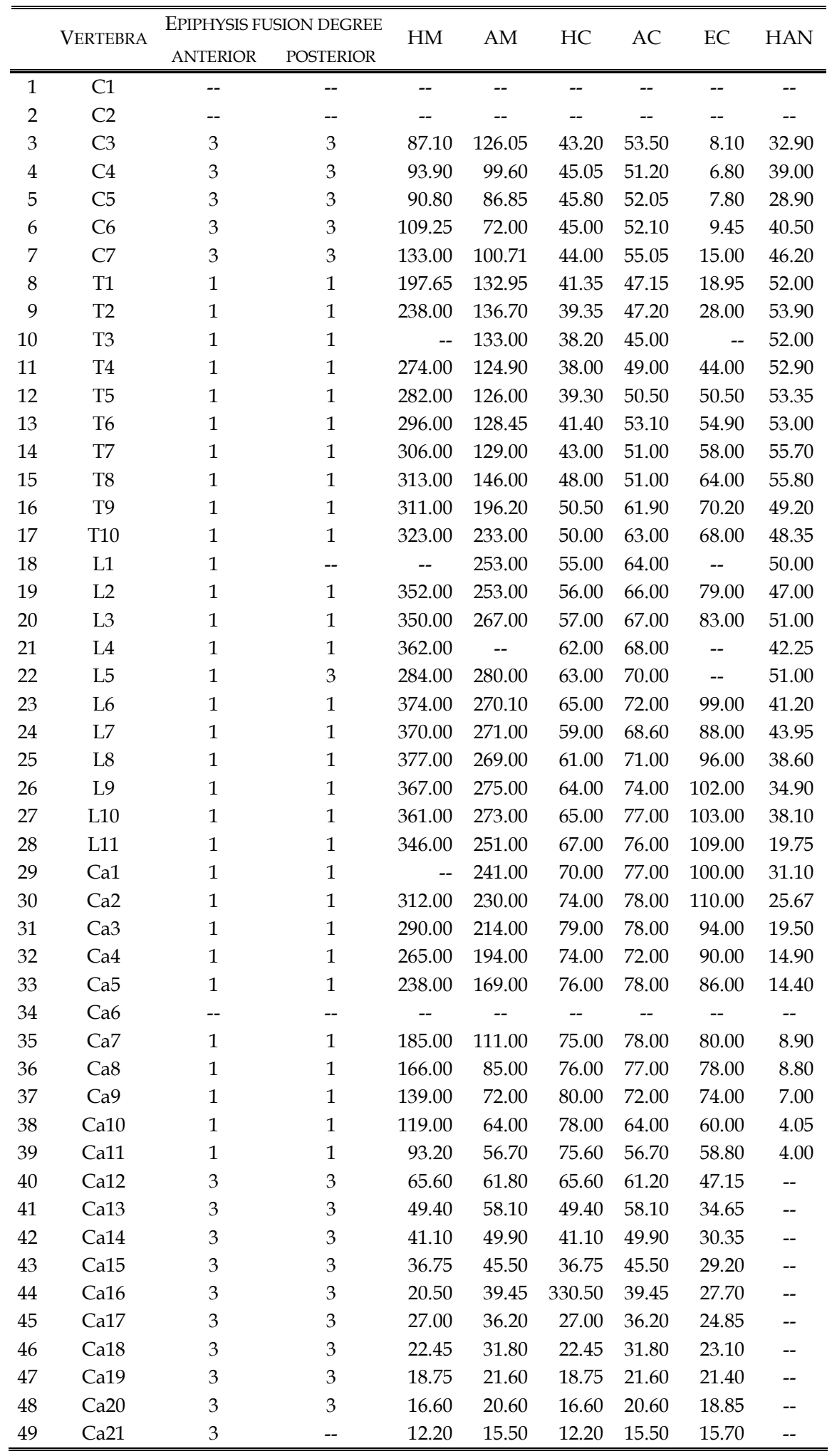

References: $\mathrm{C}=$ cervical, $\mathrm{T}=$ thoracic, $\mathrm{L}=$ lumbar, $\mathrm{Ca}=$ caudal; epiphysis fusion degree $1=$ epiphysis $0-25 \%$ fused to the centrum (unfused), $2=$ epiphysis $25-50 \%$ fused to the centrum (partially fused), $3=50-75 \%$ fused to the centrum (almost totally fused), $4=$ epiphysis 75 $100 \%$ fused to the centrum (totally fused); $\mathrm{HM}=$ Greatest height of vertebra; $\mathrm{AM}=$ Greatest width of vertebra; $\mathrm{HC}=$ Greatest height of centrum; $\mathrm{AC}=$ Greatest width of centrum; $\mathrm{EC}=$ Greatest breadth of centrum; HAN = Greatest height of neural arch. 


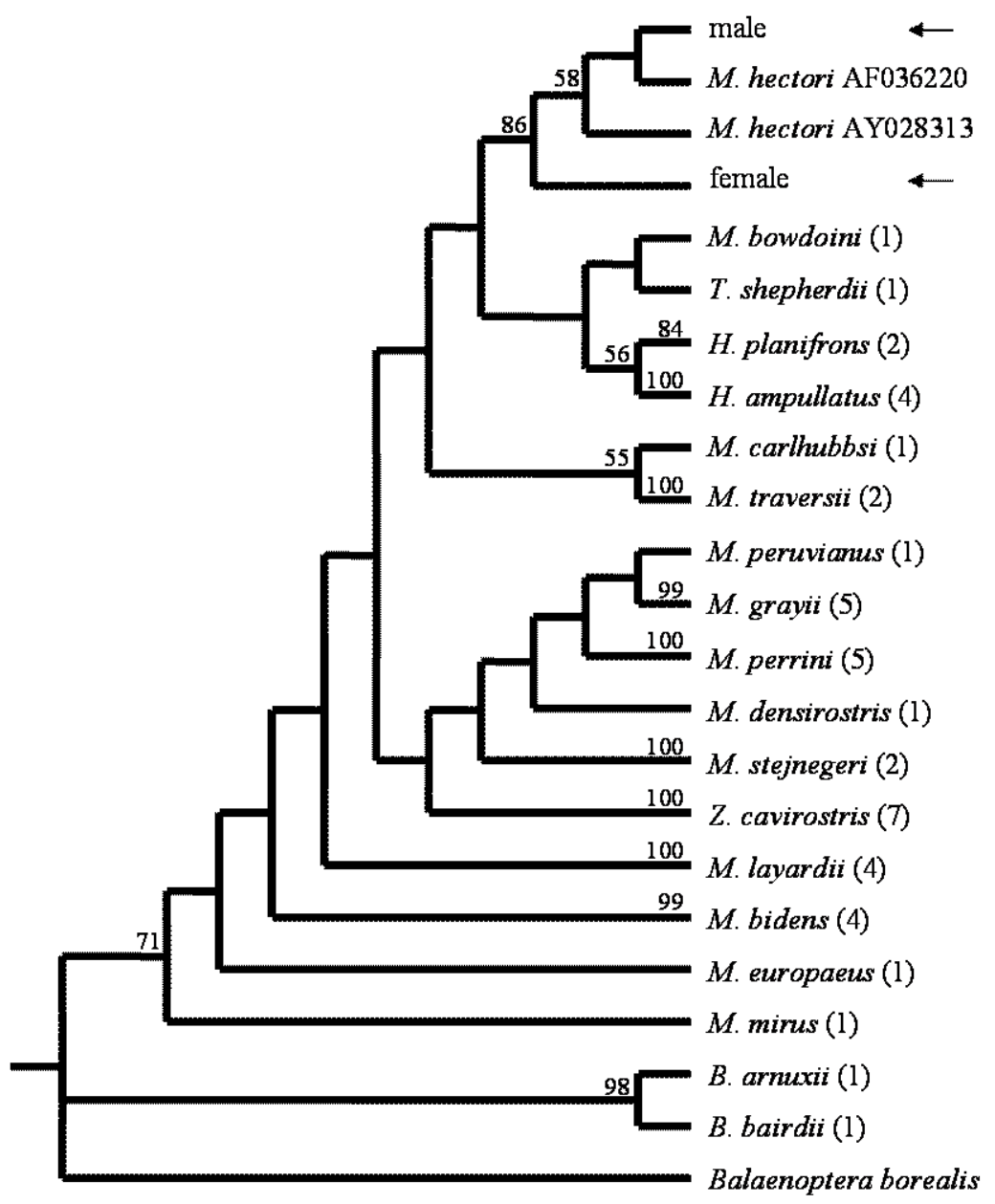

Figure 8. Phylogenetic relationship of beaked whale reference and test individuals based on $386 \mathrm{bp}$ of mtDNA control region using parsimony methods. The strict consensus tree of the two most parsimonious trees is depicted and bootstrap values $>50 \%$ based on 100 resamplings are shown. Numbers in parentheses correspond to the individuals included for each species. Sequences of both stranded individuals are indicated by arrows.

Table 4. Weight of internal organs (g) and blubber depth ( $\mathrm{mm}$ ) of a female Mesoplodon hectori stranded in Puerto Quequén, Argentina.

\begin{tabular}{lrlr}
\hline \hline \multicolumn{2}{l}{ INTERNAL ORGAN WEIGHT $(\mathrm{g})$} & \multicolumn{2}{c}{ BLUBBER DEPTH $(\mathrm{mm})$} \\
\hline \hline Heart & 3300.0 & at genital slit & 30.0 \\
Liver & 6750.0 & at cervical vertebrae & 35.0 \\
Spleen & 200.0 & at blowhole & 80.0 \\
Pancreas & 1350.0 & & \\
Stomach & 2900.0 & & \\
Lungs & 5200.0 & & \\
\hline \hline
\end{tabular}

Table 5: Percent sequence divergence of mtDNA control region sequences of both stranded Hector's beaked whales with two conspecifics, other species of the family Ziphiidae, and the outgroup used in this study (the sei whale, Balaenoptera borealis).

\begin{tabular}{lcc}
\hline \hline & FEMALE INDIVIDUAL & MALE INDIVIDUAL \\
\hline \hline Female individual & - & - \\
Male individual & $1.23 \%$ & - \\
M. hectori AY028313 & $1.25 \%$ & $0.61 \%$ \\
M. hectori AF036220 & $1.23 \%$ & $0 \%$ \\
Other species of the family Ziphiidae & $>5.28 \%$ & $>5.47 \%$ \\
Balaenoptera borealis & $22.99 \%$ & $23.52 \%$ \\
\hline \hline
\end{tabular}


Table 6: Percent sequence divergence of cytochrome $b$ sequences of both stranded Hector's beaked whales with other species of the family Ziphiidae, and with other cetacean species.

\begin{tabular}{lcc}
\hline \hline & $\begin{array}{c}\text { Female } \\
\text { Individual }\end{array}$ & $\begin{array}{c}\text { Male } \\
\text { Individual }\end{array}$ \\
\hline \hline Female individual & - & - \\
Male individual & $0.47 \%$ & - \\
Other species of the family Ziphiidae & $>9.18 \%$ & $>8.94 \%$ \\
$\begin{array}{l}\text { M. perrini, M. peruvianus, M. europaeus, M. densirostris, M. bidens, B. } \\
\text { bairdii, H. ampullatus, T. shepherdii, Z. cavirostris }\end{array}$ & $>13.2 \%$ \\
$\begin{array}{l}\text { Other Cetacean species } \\
\text { Balaenoptera borealis, Physeter catodon, Delphinapterus leucas, Orcinus orca }\end{array}$ & $>12.7 \%$ \\
\hline \hline
\end{tabular}

DNA sequences (in our case from two different mtDNA markers) can be useful as a universal character set for taxonomic identification of criptic species (Dalebout et al., 2004), particularly in circumstances where morphometric data are incomplete (e.g. broken skulls) or missing. The Witness for the Whales web page was consulted to confirm the species identification. Analysis of mtDNA sequences showed that sequence divergence between both individuals and sequence divergence of both individuals with two Australian $M$. hectori did not exceed $1.23 \%$ and $1.25 \%$, respectively. The sequence divergence of $0 \%$ (same haplotype) between the male from this study and the Australian individual suggest that the populations in Southern Hemisphere might be widely distributed and have high genetic exchange. Sequence divergence of stranded $M$. hectori with other ziphiid species exceeded 5\%, leaving no doubt about the species identity. This is of particular relevance for the identification of cryptic species of the genus Mesoplodon.

\section{Acknowledgements}

We are grateful to the people who helped us with the recovery of both stranded animals: Juan Ganga and Francisco Martínez Loydi from the Consorcio de Gestión de Puerto Quequén gave logistical support at field; Fabián Pérez, Roque Bruno from "Santa Cecilia" and Cacho helped us during the dissection of the female individual. The recovery of this individual was possible thanks to Luis Nogueira from the Estación Hidrobiológica de Puerto Quequén (MACN-CONICET). We also thank Fabián Pérez, Natalia Paso Viola, Victoria Panebianco, Darío Lijtmaer and Cecilia Kopuchian, who helped us at various stages of this study. Diego Albareda, from the Acuario de Buenos Aires, helped with the histological pathology. Tony Raga, Mercedes Fernández, Vicky Herreras and Javier Aznar, from the University of Valencia, assisted with the identification of parasites. Finally, we want to thank the technical team from Mar del Plata Aquarium who helped us with the moving of the male individual. We thank Angel Fussaro (CONICET), Carolina Ferraro, Esteban Podestá and Luis Nogueira for the photographs. We also thank Merel Dalebout, Juan Ignacio Túnez, Fabián Crespo, Valeria
Silvestroni and Natalie Goodall for their useful comments and suggestions. We are deeply grateful with the referees, Eduardo Secchi and Nélio Barros, for their contribution in improving our manuscript with wise suggestions. This study received financial support from Fundación Antorchas (HLC grant, Project A - 13672 / 1 - 3), Consejo Nacional de Investigaciones Científicas y Técnicas (PIP02193), University of Valencia, Spain (Project GV04B/304) and is a scientific contribution of the Estación Hidrobiológica de Puerto Quequén on its $78^{\text {th }}$ anniversary.

\section{References}

Baker, A.N, Duignan, P.J., Norman, R.J. De B. and van Helden, A.L. (2001) A juvenile Hector's beaked whale, Mesoplodon hectori (Gray 1871), without functional throat grooves, plus notes on endoparasites (Cetacea: Ziphiidae). Marine Mammal Science 17: 171-175.

Dalebout, M.L., van Helden, A., van Waerebeek, K. AND BaKer C.S. (1998) Molecular genetic identification of southern hemisphere beaked whales (Cetacea: Ziphiidae). Molecular Ecology 7: 687-694.

Dalebout, M.L., Hooker, S.K. And Christensen, I. (2001) Genetic diversity and population structure among northern bottlenose whales, Hyperoodon ampullatus, in the western North Atlantic Ocean. Canadian Journal of Zoology 79: 478-484.

Dalebout, M.L, Mead, J.G., Baker, C.S., BaKer, A.N. and van Helden A.L. (2002) A new species on beaked whale Mesoplodon perrini sp.n. (Cetacea: Ziphiidae) discovered trough phylogenetic analyses of mitochondrial DNA sequences. Marine Mammal Science 18: 577-608.

Dalebout, M.L., BaKer, C.S., MeAd, J.G., CockCroft, V.G. AND YAMADA, T.K. (2004) A comprehensive and validated molecular taxonomy of beaked whales, family Ziphiidae. Journal of Heredity 95: 459-473.

FLOWER, W.H. (1878) A further contribution to the knowledge of existing Ziphioid whales, genus Mesoplodon. Transactions of the Zoological Society of London 10: 415-437.

Gales, N.J., Dalebout, M.L. and Bannister, J.L. (2002) Genetic identification and biological observations of two free-swimming beaked whales: Hectors's beaked whale (Mesoplodon hectori, Gray, 1871), and Gray's beaked whale (Mesoplodon grayi, Von Haast, 1876). Marine Mammal Science 18: 544-551. 
GERACI, J.R. AND Lounsbury, V.J. (1993) Marine mammals ashore: A field guide for strandings. Texas A\&M University Sea Grant College Program. Galveston, Texas. 305 pp.

Goodall, R.N.P. (1978) Report on the small cetaceans stranded on the coasts of Tierra del Fuego. The Scientific Reports of the Whales Research Institute 30: 197-230.

HALL, T.A. (1999) BioEdit: a user-friendly biological sequence alignment editor and analysis program for Windows 95/98/ NT. Nucleic Acids Symposim Series 41: 95-98.

Henshaw, M.D., LeDuc, R.G., Chivers, S.J. and Dizon, A.E. (1997) Identifying beaked whales (Family Ziphiidae) using mtDNA sequences. Marine Mammal Science 13: 487-495.

Jauniaux, T., García Hartmann, M., Haelters, J., Tavernier, J. AND CoIGNoul, F. (2002) Echouage de mamifères marins: guide d'intervention et procédures d'autopsie. Annales Médecine Vétérinaire 146: 261-276.

LAHILLE, F. (1908) Nota sobre un delfín (Tursiops gephyreus Lah). Anales Museo Nacional de Buenos Aires, Ser. 3, T IX: 347-361.

Laporta, P., Praderi, R., Little, V. and Le Bas, A. (2005) An Andrew's beaked whale Mesoplodon bowdoini (Cetacea, Ziphiidae) stranded on the Atlantic coast of Uruguay. The Latin American Journal of Aquatic Mammals 4: 101-111.

Lichter, A.A. (1986) Records of beaked whales (Ziphiidae) from the Western South Atlantic. The Scientific Reports of the Whales Research Institute 37: 109-127.

Lichter, A.A., AND Goodall, R.N.P. (1988) Argentina: Progress report on cetacean research, June 1984 to April 1987. Report for the International Whaling Commission 38: 173-176.

Martins, A.M.A., Alves JR., T.T., Furtado Neto, M.A.A. And Lien, J. (2004) The most northern record of Gervais' beaked whale, Mesoplodon europaeus (Gervais, 1855) for the Southern Hemisphere. The Latin American Journal of Aquatic Mammals 3: 151-156.

MEAD, J. (1981) First records of Mesoplodon hectori (Ziphiidae) from the northern hemisphere and description of the adult male. Journal of Mammalogy 62: 430-432.

MeAd, J.G. (1984). Survey of reproductive data for the beaked whales (Ziphiidae). Report of the Inernational Whaling Commission (Special Issue 6): 91-96.

MeAd, J.G. (1989) Beaked whales of the genus Mesoplodon. Pages 349-430 in RiDgway, S. H. AND HarRIsON, R. (Eds) Handbook of Marine Mammals, Vol. 4. Academic Press, London. 435 pp.

MeAd, J.G. AND BAKER, A.L. (1987) Notes on the rare beaked whale, Mesoplodon hectori (Gray). Journal of Royal Society of New Zealand 17: 303-312.

Mead, J.G. (1993). The systematic importance of stomach anatomy in beaked whales. IBI Reports 4: 75-86.

MeAd, J. (2002) Beaked Whales, Overview. Pages 81-83 in Perrin, W.F., WüRsig, B. AND THEWISSEN, J.G.M. (Eds) Encyclopedia of Marine Mammals. Academic Press, San Diego, CA. 1414 pp.

Milligan, B.G. (1998) Total DNA isolation. Page 29 in Hoelzel. A.R. (Ed). Molecular Genetic Analysis of Populations - A practical approach. Oxford University Press, UK.

Moore, J.C. (1963) Recognizing certain species of beaked whales of the Pacific Ocean. The American Midland Naturalist 70: 396-428.

Moore, J.C. (1968) Relationships among the living genera of beaked whales with classifications, diagnoses and keys.
Fieldiana: Zoology 53: 209-298.

NoRRIS, K.S. (1961) Standardized methods for measuring and recording data on the smaller cetaceans. Journal of Mammalogy 42: 471-476.

Palumbi, S.R. (1996) Nucleic Acids II: The Polymerase Chain Reaction. Pages 205-247 in Hillis, D.M., MoRitz, C. AND MABLE, B.K. (Eds) Molecular Systematics. Sinauer Associates, Sunderland, MA.

PERRIN, W.F. (1975) Variation of spotted and spinner porpoises (genus Stenella) in the eastern Pacific and Hawaii. Bulletin of the Scripps Institute of Oceanography 21: 1-206.

Pitman, R.L. (2002) Mesoplodont whales (Mesoplodon spp.). Pages 738-741 in Perrin, W.F., WÜRSIG, B. ANd TheWISSEN, J.G.M. (Eds) Encyclopedia of Marine Mammals. Academic Press, San Diego, CA. 1414 pp.

Reyes, J.C. AND MolinA, D.M. (1998) Clave artificial para la identificación de cráneos de cetáceos del Pacífico Sur Este. Boletín del Museo Nacional de Historia Natural de Chile 46: 95-119.

Ross, G.J.B. (1970) The occurrence of Hector's beaked whale Mesoplodon hectori (Gray) in South African Waters. Annals of the Cape Provincial Museums (Natural History) 8: 195-204.

Ross, G.J.B. (1984) The smaller cetaceans of the south east coast of southern Africa. Annals of the Cape Provincial Museums (Natural History) 15(2): 173-410.

Sekiguchi, K., Klages, N.T.W. and Best, P. (1996) The diet of strap-toothed whales (Mesoplodon layardii). Journal of Zoology, London 239: 453-463.

SIELFELD, W.H. (1979) Consideraciones acerca de tres especies de Mesoplodon Gervais (Cetacea: Ziphiidae) presentes en las aguas chilenas. Anales del Instituto de la Patagonia, Punta Arenas, Chile 10: 181-190.

Souza, S.P., Siciliano, S., Cuenca, S. and Sanctis, B. (2005) A True's beaked whale (Mesoplodon mirus) on the coast of Brazil: adding a new beaked whale species to the western tropical Atlantic and South America. The Latin American Journal of Aquatic Mammals 4: 129-136.

StUART, L.J. AND MOREJOHN, V.G. (1980) Developmental patterns in osteology and external morphology in Phocena phocena. International Whaling Commision (Special Issue 3): 33-42.

Swofford, D.L. (2002) PAUP*. Phylogenetic analysis using parsimony ( ${ }^{*}$ and other methods). Version 4 . Sinauer Associates, Sunderland, MA.

van Helden, A.L., BaKer, A.N., Dalebout, M.L., Reyes, J.C., van WAEREBEEK, K. AND BAKER, C.S. (2002) Resurrection of Mesoplodon traversii (Gray, 1874), senior synonym of $M$. bahamondi Reyes, Van Waerebeek, Cárdenas and Yáñez, 1995 (Cetacea: Ziphiidae). Marine Mammal Science 18: 609-620.

Walker, W.A., Mead, J.G. And Brownell JR, R.L. (2002) Diets of Baird's beaked whales, Berardius bairdii, in the southern sea of Okhotsk and off the Pacific coast of Honshu, Japan. Marine Mammal Science 18: 902-919.

ZerbinI, A.N. AND SECCHI, E.R. (2001) Occurrence of the Hector's beaked whale, Mesoplodon hectori in Southern Brazil. Aquatic Mammals 27: 149-153.

Received 24 April 2005. Accepted 18 December 2005. 